\title{
Faculty Journal
}

Volume 8 (2019)

Multi-Disciplinary Research Journal of

Bulacan State University - Meneses Campus

\section{Consequences of Parental Absence due to Migration: A Qualitative Inquiry into Adolescent Students' Well-being}

\author{
Jeffrey DC. Lobos ${ }^{1 *}$, Bianca M. Juliata², \& Ericson H. Peñalba ${ }^{3}$ \\ ${ }^{1}$ Social Work Department, College of Social Sciences and Philosophy, Bulacan State University, \\ City of Malolos, Bulacan, Philippines \\ ${ }^{2}$ Guidance Office, Sitero Francisco Memorial National High School, Valenzuela City, Metro Manila, Philippines \\ ${ }^{3}$ Teacher Education Department, Bulacan State University - Meneses Campus, Bulakan, Bulacan, Philippines
}

\begin{abstract}
Overseas work has become a viable solution in addressing the problems encountered by one out of every 12 Filipino families. Although it has brought opportunities for a better and financially stable life, it has resulted in inevitable consequences that could affect children who are left behind. This study explored perceptions of six adolescent students regarding such consequences of being geographically separated from their parents on their well-being. The thematic analysis of the responses obtained from in-depth interviews generated a total of four dominant themes, namely seeking opportunities for sustaining family needs, having indebtedness toward parents, longing for parental love and care, and facing the negative consequences of parental absence. These themes provided further evidence on how the changing dynamics in family relationships, as brought about by migration and parental absence, could have negative consequences, particularly on their emotional well-being. This study has shown that the interviewees experienced varied negative emotions arising from the acknowledgment of the sad reality that they were left behind, having to endure an increasing relationship gap with their parents. The themes, however, indicated positive perceptions as regards how the interviewees valued the sacrifices of their parents. The results were used to develop a framework for a social work-based program for enrichment and enhancement of the well-being of children of migrant workers.
\end{abstract}

Keywords: parental absence, migration, students, well-being, thematic analysis

\section{Introduction}

In the Philippines, the persistent problem of unemployment continues to affect families, making overseas work a viable option for addressing such a condition. After all, the opportunity that can be realized from working abroad is not only aimed at improving living standards but also, at a larger scale, directing investments towards the development of the human capital, resulting in more employment prospects (Edillon, 2008). In the 2018 survey of overseas Filipino, the Philippine Statistics Authority (PSA) reported that the total number of Overseas Filipino Workers (OFWs)

*Corresponding Author: Jeffrey DC. Lobos

e-mail: jeffrey.lobos@bulsu.edu.ph

(c) The Author(s) 2019. This is an Open Access article distributed under the terms of the creative commons Attribution 4.0 license (http://creativecommons.org/licenses/by/4.0), which permits unrestricted use, distribution, and reproduction in any medium, provided the original work is properly cited.

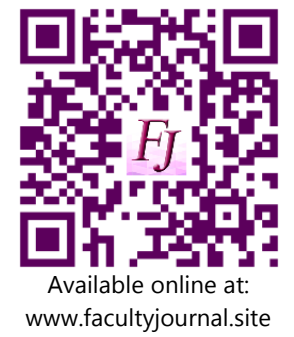


reached 2.3 million, noting that the remittances they sent to their respective families may just be a part of the total salary" they received (para. 7).

By regarding overseas work as a solution to family-related problems, especially those concerning how to achieve financial stability, Filipino family structures have evolved throughout the years. As confirmed by the 2017 Social Weather Station (SWS) survey, there was at least one family member who works abroad in one out of every 12 families. Mangahas (2017) noted that these families came from different sectors, and they were most likely not to be economically deprived.

With the increasing number of Filipino migrant workers, families are challenged not only in terms of sustaining their children's needs but also in assuring them the support they need despite the geographical distance. A key issue faced by OFW families is parental absence, which then translates into a lack of emotional support for their children that would eventually negatively impact the latter's welfare (Asis \& Ruiz-Marave, 2017).

In order to guarantee support and communication systems to strengthen their ties and connections with their children despite the distance, parents resort to asking help from their relatives who would oversee their loved ones they have left behind (Kilkey \& Merla, 2011). The wide availability of mobile technologies and applications like Facebook and Skype has helped in removing feelings of sadness and loneliness, which could be both experienced by migrant parents and their children.

The relationship between parents and their children has been shifting in a manner that continuously reshapes views about parenting. This condition has resulted in questions regarding the adverse effects that parental absence could have on the well-being of children who are left behind. In this study, children's well-being pertains to their psychological, health, and educational outcomes (Mazzucato \& Schans, 2011). In particular, emotional well-being is considered a determinant of how children would decide, behave, and cope when confronted with complex situations brought about by parental migration and absence. In the local context, Jordan and Graham (2012) found that "children of migrant parents in the Philippines had a relative advantage in terms of psychological well-being compared to their peers in nonmigrant households" (p. 1675).

Past studies on the consequences of parental absence on children's well-being drew insights from children and teenagers whose perspectives provide a more in-depth understanding of their experiences as left-behind individuals. Zhao et al. (2018) found that children experienced challenges to their psychosocial well-being primarily caused by long-term separation from their parents. These left-behind children experienced emotional distress, which was reflected in their experiences of loneliness and sadness. The authors further found that parental migration was deemed as the best choice to improve the family's welfare. Lam and Yeoh (2019) explored how the need to sacrifice for the 'greater food of the family' influenced parents' decision for migration and served as children's starting point for understanding and accepting such a decision. They further found out that eventually, children would resort to measures to convince their parents to go back home. Isaacs (2012) identified the negative effects of being separated from parents, noting how it could lead to a feeling of being abandoned and how reunion after several years of separation could result in conflict. Graham and Yeoh (2013) highlighted the likelihood of experiencing a care deficit among adolescents. They noted, however, that such deficit could be filled by the "support and assistance provided by extended family members" (p. 303).

This research is based on the context that experiences and perceptions of left-behind adolescent students could provide a rich understanding of the consequences of parental migration to their well-being. It adds to the limited literature that exists for qualitative studies on this particular research area. Therefore, this research aims to shed light on such consequences, which 
would then be beneficial in crafting a framework for enriching and enhancing left-behind children through a social-work based program.

\section{Materials and Methods}

This study utilized a qualitative research design. In-depth interviews were carried out with purposively selected six adolescent students to explore their experiences and perceptions as children of migrant worker parents. They lived with their relatives or guardians in Bulacan province and Valenzuela City. They were chosen based on the following criteria: their age must range from thirteen (13) to nineteen (19) years old and have parents working abroad for not less than three years.

A semi-structured questionnaire, containing 11 questions, was prepared. The questions dealt with reasons why their parents had to work abroad, perceptions of their conditions of having migrant work parents, the status of their relationships with their parents and other family members, and their feelings towards their situation. Each participant was given an informed consent that details the objectives of the research and the permission for them to be a part of the study.

The interviewees' responses were audio recorded on a smartphone and transcribed. Using the popular analytic tool for qualitative research developed by Attride-Stirling (2001), the transcription was transformed into a code material, in which the texts were analyzed and coded to produce themes. The themes became the basis for the creation of thematic networks.

\section{Results and Discussion}

\section{Thematic Network Analysis Results}

As shown in Table 1, the thematic network analysis of the interview responses resulted in four dominant organizing themes, namely seeking opportunities for sustaining family needs, having indebtedness toward parents, longing for parental love and care, and facing the negative consequences of parental absence. The said themes transpired from the generated 20 codes, which were further organized into 14 basic themes. The resulting organizing themes comprise the global theme: Consequences of parental absence on adolescent students' well-being due to migration. The organization of codes and themes are illustrated in Figure 1. Each theme is explored in the following sections.

\section{Seeking opportunities for sustaining family needs}

The interviewees were all aware of the primary reasons why their parents had to leave. The opportunities that could be sought abroad were aimed at sustaining their long-term needs as these could not be provided if they worked locally. Since their parents prioritized their basic needs, it was no wonder why they decided to leave the country. As stated by a participant:

"I think the reason why my mom has been working abroad is to provide our needs and also to support my grandparents who are taking care of us while my mom is away." 
Table 1

Global theme: Consequences of parental absence on adolescent students' well-being due to migration

\begin{tabular}{|c|c|c|}
\hline Codes & Basic Themes & Organizing Themes \\
\hline $\begin{array}{l}\text { Scarcity in family resources } \\
\text { Availability of work opportunities } \\
\text { Prioritizing basic needs } \\
\text { Seeking 'greener pasture' } \\
\text { Thinking about the family's future } \\
\text { Giving family a better and } \\
\text { comfortable life }\end{array}$ & $\begin{array}{l}\text { Provision for family's primary } \\
\text { needs } \\
\text { Greater opportunity in } \\
\text { employment } \\
\text { Sustenance of daily needs } \\
\text { Facing financial challenges }\end{array}$ & $\begin{array}{l}\text { Seeking opportunities } \\
\text { for sustaining family } \\
\text { needs }\end{array}$ \\
\hline $\begin{array}{l}\text { Pain caused by separation } \\
\text { Difficulty in communication due to } \\
\text { distance } \\
\text { Changing relationship status with } \\
\text { parents } \\
\text { Being used to having an OFW } \\
\text { parent } \\
\text { Coping up with the absence }\end{array}$ & $\begin{array}{l}\text { Grief over departure } \\
\text { Limited communication with } \\
\text { family members } \\
\text { Relationship gap between parents } \\
\text { and children } \\
\text { Accustomed to having distant } \\
\text { relationship with parents }\end{array}$ & $\begin{array}{l}\text { Facing the negative } \\
\text { consequences of } \\
\text { parental absence }\end{array}$ \\
\hline $\begin{array}{l}\text { Sacrificing for the family } \\
\text { Having to live away from } \\
\text { parents/children } \\
\text { Thinking about parents' hard work } \\
\text { Being left behind } \\
\text { Stories of struggles of being part } \\
\text { of an OFW family }\end{array}$ & $\begin{array}{l}\text { Appreciation for parents' hard } \\
\text { work } \\
\text { Giving back the favor for parents' } \\
\text { sacrifices } \\
\text { Sharing stories of experiences of } \\
\text { living and working away from } \\
\text { families }\end{array}$ & $\begin{array}{l}\text { Having indebtedness } \\
\text { toward parents }\end{array}$ \\
\hline $\begin{array}{l}\text { Difficulty in moving forward after } \\
\text { parents 'departure } \\
\text { Feeling sad and alone } \\
\text { Always thinking about their } \\
\text { parents' conditions } \\
\text { Fear and anxiety }\end{array}$ & $\begin{array}{l}\text { Sense of loneliness } \\
\text { Longing for the presence of } \\
\text { parents } \\
\text { Feeling of emptiness }\end{array}$ & $\begin{array}{l}\text { Longing for parental } \\
\text { love and care }\end{array}$ \\
\hline
\end{tabular}

Due to the availability of work opportunities abroad, their parents were attracted to the idea of seeking 'greener pasture' and providing better lives for their families. It was as if this was the only way for them to get away from the financial burden. This condition was evident in this statement:

"Because of financial needs and the debts our family has to pay, my mother chose to work abroad as the salary is a lot higher there than here."

This organizing theme reflects the sad plight of some Filipino families who do not have any choice but to seek an opportunity that would result in an easier way to earn income. While this may be a painful situation for them, the decision of their parents to work abroad seems to be a necessary sacrifice to be made. This situation becomes even more difficult for parents that had to go through a combination of problems. A participant shared:

"Because my mom is a single parent, she has to work for us. Her salary in her previous work here is not enough to sustain our needs, especially that I am in college now." 


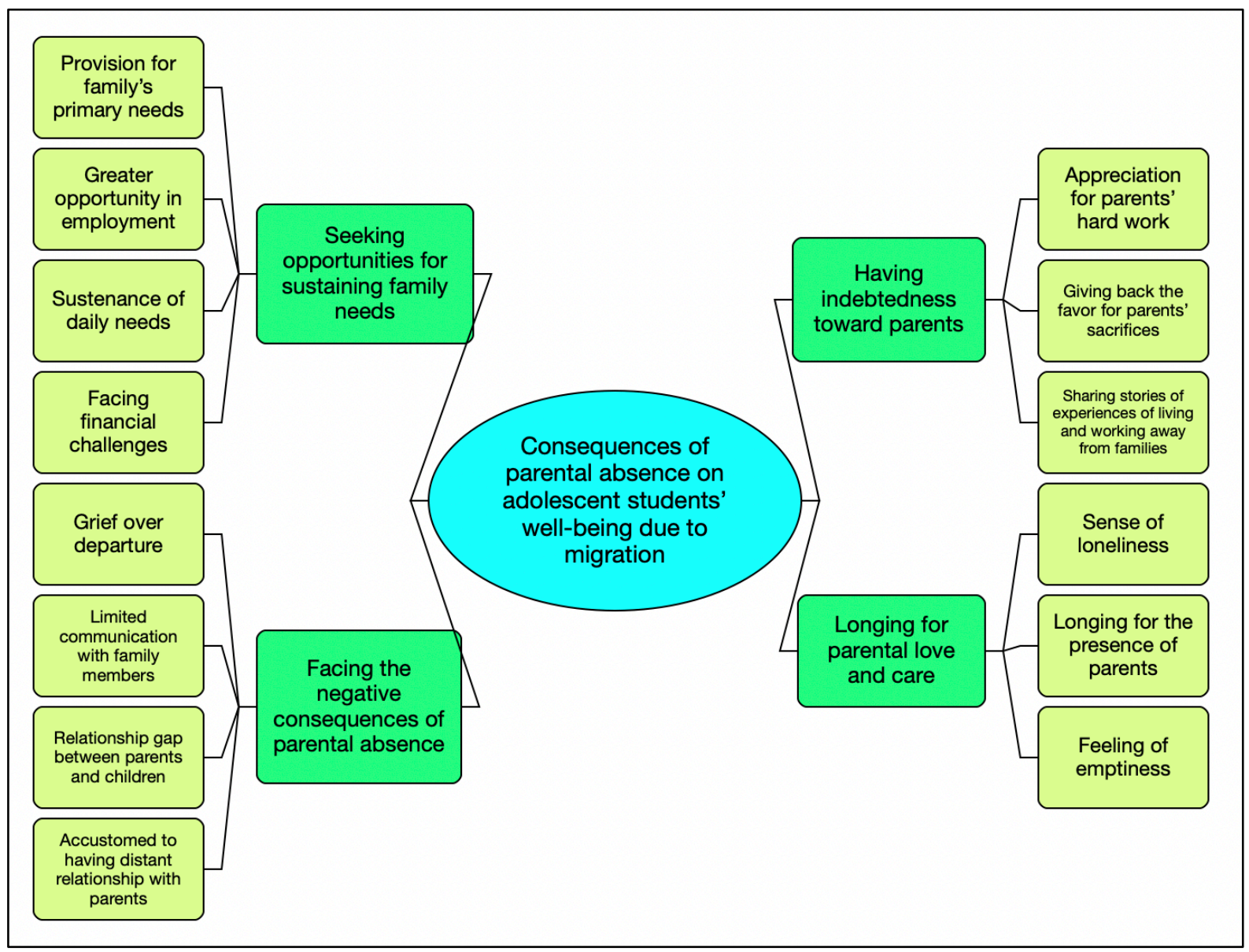

Figure 1. Thematic network of consequences of parental absence on adolescent students' wellbeing due to migration

The interviewees' awareness of the reason for their parents' migration reflects the idea that seeking opportunities was the only way to survive and achieve prosperity. This finding further supports the idea of Zhao et al. (2018), revealing the hard truth about migrant workers who were willing to sacrifice for the welfare of their families. Lam and Yeoh (2019) shared this perspective as they found out that sacrifice, in the context of migration among Filipino parents, had to be done for the family's welfare. As confirmed in this study, the concept of sacrifice was necessary, and it was the only action that had to be carried out by migrant parents.

\section{Facing the negative consequences of parental absence}

All of the interviewees felt sad when their parents informed them of their decision to work abroad. Questions came to light as to how they would live, knowing that their parents would no longer be around to attend to their needs. It was especially difficult for interviewees who had to experience being left behind at an early age. As shared by the interviewees:

"She started working abroad since I was young. As a child, I found it hard to be apart from my mom, but as time passed by, I understood the situation why she had to do it for us."

"I could not even remember when my mom left when I was three months old. If I can turn back time at that moment, I would feel sad and longing for her. In my opinion, it is really very different if children grow up with their parents." 
Eventually, they got used to having an OFW parent. However, there were moments when they realized that something was lacking in their lives. They admitted that a relationship gap might have already existed between them and their parents. This situation further facilitated sadness, loneliness, and other emotional problems. One participant described his father's love as 'empty.' For two other interviewees, parental absence turned out to be a motivation to strive harder in their studies and to be independent in their decisions. They said:

"Sadness and happiness. I felt sad when she had to be apart from us for a long period when I could no longer feel the presence of a parent. I felt happy as I learned to be strong and turned this as my motivation to study even more."

"I learned to be independent and be financially conscious as I had no one to depend on regarding financial needs as they not there always and most of their support for my siblings."

Maintaining a close family relationship had been very difficult for almost all of the interviewees, even before their parents left. Such difficulty stems from their limited communication with family members, inability to express their feelings, being uncomfortable in their presence, and missing the warmth of family. These had resulted in a relationship gap between them and their parents, as reflected in these statements:

"I rarely speak with my parents. I do not know how to converse with them. I only talk to them if my siblings are around."

"At first, I did not have a good relationship with my parents. As I became a teenager, I started to understand what was happening. Currently, I have a good relationship with them."

However, when their parents returned home even for a short period, they would show a rather opposite reaction. The interviewees mentioned how happy they were to be reunited with them, indicating that their relationship with their parents as 'good.' It was worth mentioning that the nature of their relationships could change, as verbalized in this specific statement:

"Our relationship is different when she is here and when she is abroad. We seldom talk

when she is here. But I often say I love you and I miss you when she is abroad."

Inevitably, one of the consequences that is most likely to be experienced due to separation from migration from parents is emotional distress (Zhao et al., 2018). Given the long period of being separated from each other, it was natural for left-behind children to experience sadness and loneliness. As emphasized by Isaacs (2012), separation from parents could be a contributing factor to having a feeling of abandonment. The finding in this study, nevertheless, reveals that it was still possible for children to foster a good relationship with their parents despite their struggles to fill in a relationship gap for such a long period.

\section{Having indebtedness toward parents}

As they acknowledged the sacrifices made by their parents, the interviewees developed a sense of gratitude towards them. Notably, they highlighted how their parents had endured all the struggles as migrant workers. They noted how tough it was for them to be away from their parents, but they realized that it was more difficult for their parents to live through such struggles in a distant place.

It was then inevitable for the interviewees to transform their sense of gratitude into a debt of gratitude. A typical response was about their desire to strive harder and to show to their parents that they were willing to give back the favor. They mentioned that by finishing their studies, they could finally pay their parents back for all their sacrifices. Two interviewees commented: 


\section{"I can repay them by finishing my studies and by living uprightly. I can support them if}

I have a decent job."

"Of course, to finish my studies. My mom would always remind me of it. I should study well and help at home."

Adhering to the cultural value of having 'utang na loob'somehow made them morally bound to reciprocate their parents' sacrifices. This adherence illustrates a deep sense of respect towards their parents, a value that is expected to be acquired by Filipino children (Alampay \& Jocson, 2011). A participant captured this idea when he said: "Of course, they are our parents. I need to 'return to them' whatever / have right now. "Eventually, this could only be actualized when they already find jobs, which was the only way for them to convince their parents to stop them from working abroad.

\section{Longing for parental love and care}

After their parents' departure, the interviewees experienced difficulty in moving forward with their lives. It was even more challenging upon knowing that their parents would only return every after two years. Two of them were not sure at all when they would return, stating: "They have not returned home since they left."

While they admitted that they would usually feel sad and alone and be worried about their parents' conditions, they recognized their parents' efforts to check their situations from time to time. To make their presence felt, their parents made sure that they found time to catch up with them, know if they are experiencing problems, and even go home during essential occasions and emergencies. As narrated by two interviewees:

"They are always around for my siblings and me whenever we encounter problems.

They call us every day, and I can feel their presence."

"When my sister was hospitalized, we needed her badly. And my mom went home."

Moreover, although they may not have enjoyed sufficient parental presence, they were still thankful for the adequate support provided to them by their parents. However, if given another option, they still wanted their parents to live with them at home, which they regarded as priceless compared to the material things they received from them. The following verbalizations support this:

"It is more than enough. I should say I need them more than the things they give. But

I fully understand why they have to leave."

"No amount of money or gifts from abroad can replace a mother's love and care."

The desire for love and care was a natural response among the interviewees, particularly in the context of long-term separation. This demonstrates what Graham and Yeoh (2013) described as care deficit, which could then be filled by other members of the family. In this study, the provision for such support and assistance did not appear in the responses. The interviewees, although stating that they really longed for their parents, noted that they were still able to get adequate support from them. 

Framework for a social work-based program for enrichment and enhancement of the well-being
of children of migrant workers

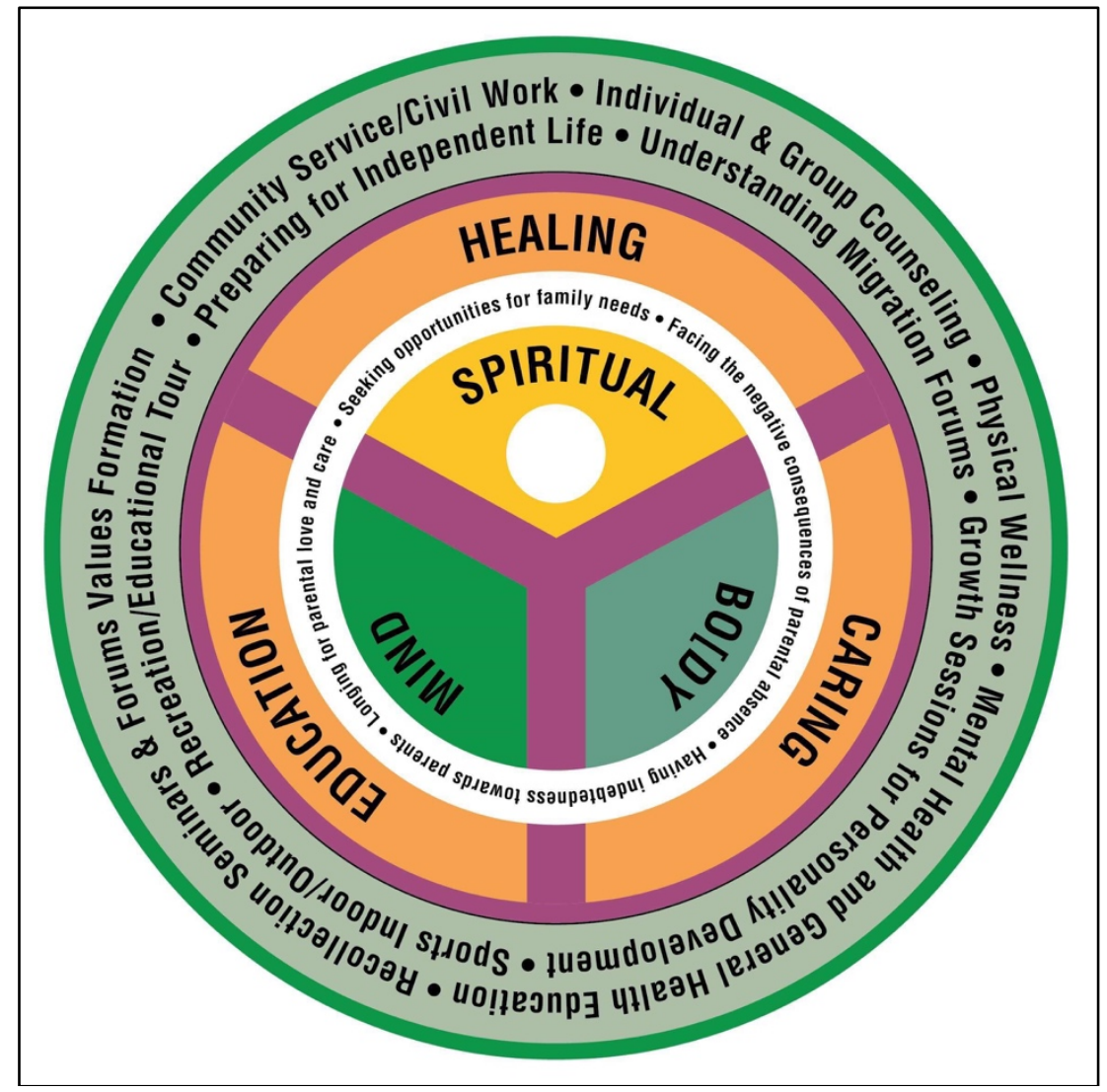

Figure 2. Framework for a social work-based program

This qualitative investigation resulted in a formulation of a structure of a program enhancement for the children of migrant workers (Figure 2) based on the four dominant organizing themes namely: seeking opportunities for family needs, facing the negative consequences of parental absence; having indebtedness towards parents, and longing for parental love and care.

The intervention system is placed on a round and closed structure. Within the circle are activities that can be implemented by professionals not only to assess the condition of children in OFW families but also to enhance their well-being. The structure is proposed as an improvement program attending to the parts of the human individual on a tri-overlap approach: Healing, Caring, and Educating. These three noteworthy angles are coordinated together to guarantee that there is an all-encompassing improvement of the left-behind children.

The 'caring' side of this enhancement program will bargain fundamentally on the 'body' of the human individual, which can be conveyed through games exercises. The exercises will concentrate on the improvement of their physical bodies so they will probably keep up their wellbeing and health; the games exercises will be expected to improve their social associations with others. These activities will serve as opportunities for social interaction and setting up a care group. The game exercises will be based on the interests of the children. Visits can be done on a semestral or yearly basis to facilitate the monitoring of their condition.

The 'knowledge' or the education side of this enhancement program, which is coordinated to the 'mind' of the human individual, will give the handle on setting them up for autonomous life. This enhancement aspect will allow them to be prepared in facing their personal problems. The 
Guidance Office, in particular, can provide activities that are aimed at improving their viewpoints and making them more resilient in coping with their situation.

The 'healing' angle is an essential measurement in the improvement program since this perspective manages the intangibles in the human individual. The intangibles are the feelings and sentiments that are not frequently verbalized but instead will have an extraordinary bearing on the totality of the individual. These are viewpoints that require further understanding of the emotions experienced by children.

\section{Conclusions}

This qualitative inquiry explored the consequences encountered by the interviewees in having parents who were migrant workers. The findings reveal that despite their full awareness of the reasons why their parents had to leave, they had to deal with mostly negative consequences of parental absence on their well-being. Generally, they experienced negative emotions such as loneliness, grief, sadness, anxiety, fear, and even feeling of emptiness. Such emotions emanated from the difficulty of moving forward after being separated from their parents, increased relationship gap, limited opportunities for communication, and acknowledgment of their parents' sacrifices. Nevertheless, the interviewees still exhibited positive perceptions as they showed their sense of appreciation towards their parents through the recognition and practice of 'utang na loob' value and their continuous longing for parental love and care.

\section{References}

Alampay, L. P., \& Jocson, R. M. (2011). Attributions and attitudes of mothers and fathers in the Philippines. Parenting, Science and Practice, 11(2-3), 163-176. https://doi.org/10.1080/15295192.2011.585564

Asis, M. M., \& Ruiz-Marave, C. (2013). Leaving A Legacy: Parental Migration and School Outcomes Among Young Children in the Philippines. Asian and Pacific migration Journal: APMJ, 22(3), 349-376. https://doi.org/10.1177/011719681302200303

Attride-Stirling, J. (2001). Thematic networks: An analytic tool for qualitative research. Qualitative Research, 1(3), 385-405. https://doi.org/10.1177/146879410100100307

Ayala, T. (2017). Children "Left Behind": Exploring the Nexus of Migration and Formal Education in Mexico.

Edillon, R. V. (2008). The effects of parent's migration on the rights of children left behind in the Philippines.

UNICEF. https://www.unicef.org/socialpolicy/files/Philippines_The_Effects_of_Parents_Migration_on_t he_Rights_of_Children_Left_Behind.pdf

Graham, E., \& Yeoh, B. S. (2013). Child health and migrant parents in South-East Asia: Risk and resilience among primary school-aged children. Asian and Pacific Migration journal: APMJ, 22(3), 297-314. https://doi.org/10.1177/011719681302200301

Hanson, J.M. (2013). Understanding graduate school aspirations: The effect of good teaching practices. [Doctoral dissertation, University of lowa]. lowa Research Online. https://doi.org/10.17077/etd.wcgna3vn

Isaacs, C. E. (2012). The influence of single-mother migration on social and emotional adjustment of Jamaican adolescents. [Doctoral dissertation, Ball State University]. Cardinal Scholar. 
https://cardinalscholar.bsu.edu/bitstream/handle/123456789/196980/IsaacsC_2012-

1_BODY.pdf;jsessionid=6EA691C6A29043CA1A2003C1C09C9B9A? sequence $=1$

Jordan, L. P., \& Graham, E. (2012). Resilience and well-being among children of migrant parents in South-East Asia. Child development, 83(5), 1672-1688. https://doi.org/10.1111/j.14678624.2012.01810.x

Kilkey, M., \& Merla, L. (2011, July 4-6). Transnational Families' care-giving arrangements: Towards a situated transnationalism [Paper presentation]. Social Policy Association Annual Conference, Lincoln, United Kingdom. http://www.socialpolicy.org.uk/lincoln2011/kilkey_merla\%20P4.pdf

Lam, T., \& Yeoh, B.S.A. (2019). Parental migration and disruptions in everyday life: reactions of leftbehind children in Southeast Asia. Journal of Ethnic and Migration Studies, 45(16), 30853104. https://doi.org/10.1080/1369183X.2018.1547022

Mangahas, M. (2017, September 30). Overseas workers' families are less poor. Philippine Daily Inquirer. https://www.inquirer.net/

Philippine Statistics Authority. (2019). Total number of OFWs estimated at 2.3 million (Results from the 2018 survey on overseas Filipinos). (Press release no. 2019-103). https://psa.gov.ph/content/total-number-ofws-estimated-23-million-results-2018-surveyoverseas-filipinos-0

Mazzucato, V., \& Djamila, S. (2011). Transnational Families and the Well-Being of Children: Conceptual and Methodological Challenges. Journal of Marriage and Family, 73, 704-712. https://doi.org/10.1111/j.1741-3737.2011.00840.x.

Zhao, C., Wang, F., Zhou, X., Jiang, M., \& Hesketh, T. (2018). Impact of parental migration on psychosocial well-being of children left behind: A qualitative study in rural China. International Journal for Equity in Health, 17(1), 80. https://doi.org/10.1186/s12939018-0795-z 